TAPROBANICA, ISSN 1800-427X. December, 2013. Vol. 05, No. 02: pp. 138-139, 1 pl. (C) Taprobanica Private Limited, 146, Kendalanda, Homagama, Sri Lanka.

http://www.sljol.info/index.php/tapro

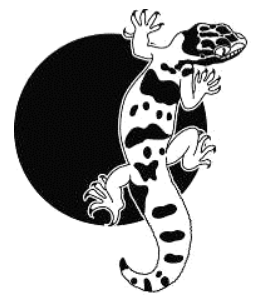

\section{Rediscovery of Henckelia macrostachya (Gesneriaceae) from Kerala, India}

During the recent floristic exploration to Anaimudi and its surroundings, the highest peak in southern India, one of the authors collected a gesneriad herb from Pettimudi at an altitude of $2000 \mathrm{~m}$ in the Idukki District of Kerala State. The taxonomic identity of the specimen has been determined as Henckelia macrostachya (E. Barnes) A. Weber \& B. L. Burtt (Didymocarpus macrostachya E. Barnes). Subsequent perusal of the literature and consultation of different herbaria (CAL, K, $\mathrm{MH}, \mathrm{TBGT}$ ), the present collection proved to be a rediscovery of the species after a lapses of 75 years from its original collection. The species was collected at Ottaparai Ridge at an altitude of 5500 feet near Munnar, the foothills of the Anaimudi Range. The species could not be located although the area has been well explored by various authors (Sebastine \& Vivekananthan 1967; Shetty \& Vivekananthan 1971, 1975, 1991; Pandurangan 1990) and therefore was treated recently as possibly extinct (Nayar, 1997). The rediscovery of the species confirmed its existence in the wild and hence assumes significance from conservation point of view. Based on the field observation, morphological assessment, and a nomenclatural review, a detailed description is provided with illustration and photographs to facilitate its identification (Figs. 1-4).

\section{Henckelia macrostachya (E. Barnes) A.} Weber \& B. L. Burtt (1998)

Beitrage zur Biologie der Pflanzen 70: 349. 1998, based on Didymocarpus macrostachyus E. Barnes in C. E. C. Fischer, Bulletin of Miscellaneous Information (Royal Gardens, Kew) 1938: 37. 1938.

Herbs Lithophytic perennial, scapose. Leaves radical in rosette; blades oblong to narrowly ovate, 11-27 x 4-12 cm, coriaceous, dull-green and velvety with a dense mat of curved hairs above, pale-brown below, abruptly narrowed basally, obscurely crenate marginally, rounded apically; lateral nerves 6-9 pairs. Scapes 1 or more, rather stout, terete, erect, grooved on 2 opposite sides, up to $60 \mathrm{~cm}$ long, densely palebrown tomentose; bracts minute. Calyx-lobes ovate, obtuse, $0.6 \times 0.3 \mathrm{~cm}, 3$ broad, 2 narrow, glabrous and 3-nerved within, densely tomentose without. Corolla broadly campanulate, ca 1 x $2 \mathrm{~cm}$ across, oblique; lobes orbicular, pale-blue, downy without and dotted with small, sessile glands. Stamens 2; filaments ca $2.5 \mathrm{~mm}$ long; anthers spherical, ca $1.5 \mathrm{~mm}$. diam.; staminodes 2, slender, ca 2.5 $\mathrm{mm}$ long with curved or hooked ends. Ovary tomentose; style $3 \mathrm{~mm}$ long; stigma not wider than style. Capsules linear, stout, $1.5-2.5 \mathrm{~cm}$ long, acute, light-brown tomentose. Seeds minute, ovoid, flattened.

Specimens examined: Ottapari Ridge, near Munnar, Idukki District, Kerala, 17 Sep 1935, E. Barnes 1266 (K!); Pettimudi, 2000 m, 30 Oct 2012, Shaju \& Shareef, s.n. (TBGT, 74028)

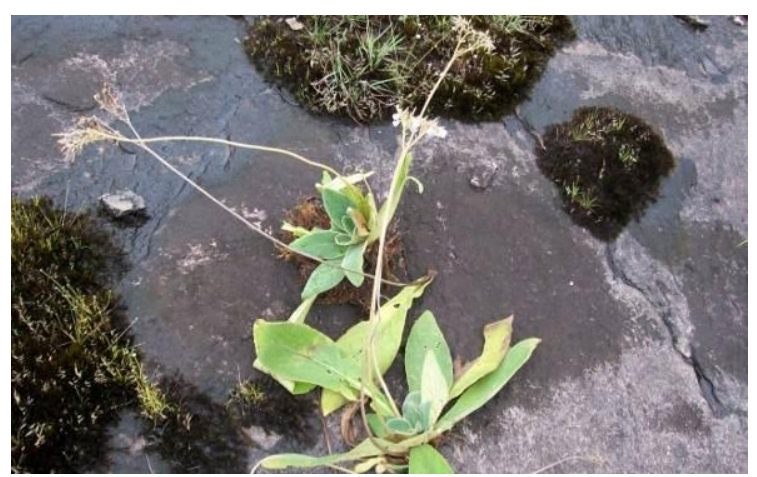

Figure 1: H. macrostachya habit and habitat

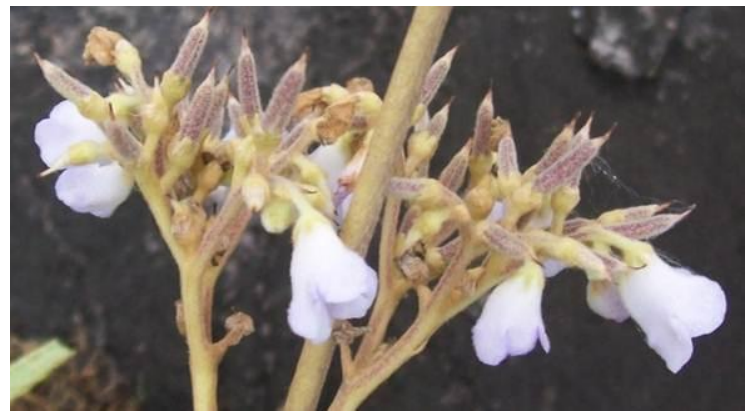

Figure 2: H. macrostachya Inflorescence 


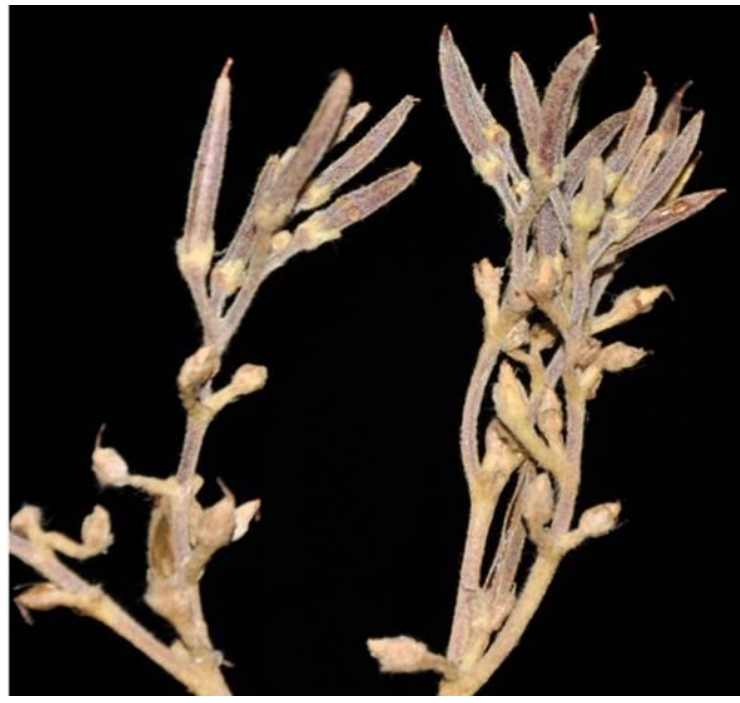

Figure 3: H. macrostachya fruiting branch

Flowering \& Fruiting: August-September.

Habitat: Growing on wet rocks in cushion of moss.

During the present study a few specimens were collected in and around Pettimudi, adjacent to the type locality. The species is possibly surviving as fragmented populations in a narrow range of distribution, being subjected to habitat alteration/destruction due to plantation activities so that the remaining populations face an uncertain future.

The genus Didymocarpus was established by Wallich in 1819 and since then it has been defined to accommodate species of different morphology, affinities, and geographical origins. Therefore A. Weber \& B. L. Burtt (1998) remodeled the genus and recognized three genera, proposing Hovanella A. Weber \& B.L. Burtt in addition to Didymocarpus Wall. s.str. and Henckelia Spreng. Some species of Didymocarpus were transferred to Henckelia with an objective of establishing more natural taxonomic units.

The genus Henckelia was established by Curt Polycarp Joachim Sprengel in 1817 to honour Count Leo Victor Felix Henckel von Donnersmarck (1785-1861), a German amateur botanist. The name Henckelia has priority over Didymocarpus, but in view of wider usage, the latter name is conserved until Henckelia was reestablished by A. Weber \& B. L. Burtt in 1998 to accommodate the southeastern Asian species of Didymocarpus.

\section{Acknowledgements}

The authors are thankful to P. G. Latha (Director, JNTBGRI) for the facilities and constant encouragements. They are also grateful to M. P. Geetha Kumary, Technical Officer, P. E. Roy and Ahmadul Kabeer, Research fellows for their help.

\section{Literature cited}

Fischer, C. E. C. 1938. New or little known plants from south India. Bulletin of Miscellaneous Information (Royal Gardens, Kew), 1938: 32-37.

Nayar, M. P., 1997. Biodiversity challenges in Kerala and science of conservation biology. Pp. 7-80, In: Pushpangadan, P. and K. S. S. Nair (eds.). Biodiversity of Tropical Forest. The Kerala Scenario. STEC Government of Kerala.

Sebastine, K. M. and K. Vivekananthan, 1967. A contribution to the flora of Devicolam, Kottayam District, Kerala. Bulletin of Botanical Survey of India, 9: 163-185.

Shetty, B. V. and K. Vivekananthan, 1971. Studies on the vascular flora of Anaimudi and the surrounding regions, Kottayam district, Kerala. Bulletin of Botanical Survey of India, 13: 16-42.

Shetty, B. V. and K. Vivekananthan, 1975. New and little known taxa from Anaimudi and surrounding regions, Devicolam, Kerala 6 - An undescribed species of Oberonia Lindl. Bulletin of Botanical Survey of India, 17: 157-159.

Shetty, B. V. and K. Vivekananthan, 1991. The endemic and endangered plants of the high range, Idukki district, Kerala. Pp. 230-236, In: Karunakaran, C. K. (ed.). The Proceedings of the Symposium on Rare, Endangered and Endemic plants of the Western Ghats. Kerala Forest Department, Thiruvananthapuram.

Weber, A. and B. L. Burtt, 1998. Remodelling of Dydymocarpus and associated genera (Gesneraceae). Beitrage zur Biologie der Pflanzen, 70: 293-363.

Submitted: 8 May 2013, Accepted: 31 October 2013 Sectional Editor: James L. Reveal

T. Shaju, M. Rajendraprasad, S. M. Shareef, A. R. Beegam \& A. G. Pandurangan

Jawaharlal Nehru Tropical Botanic Garden \& Research Institute, Palode, Thiruvananthapuram 695562 Kerala, India 


\section{PLATE 3}

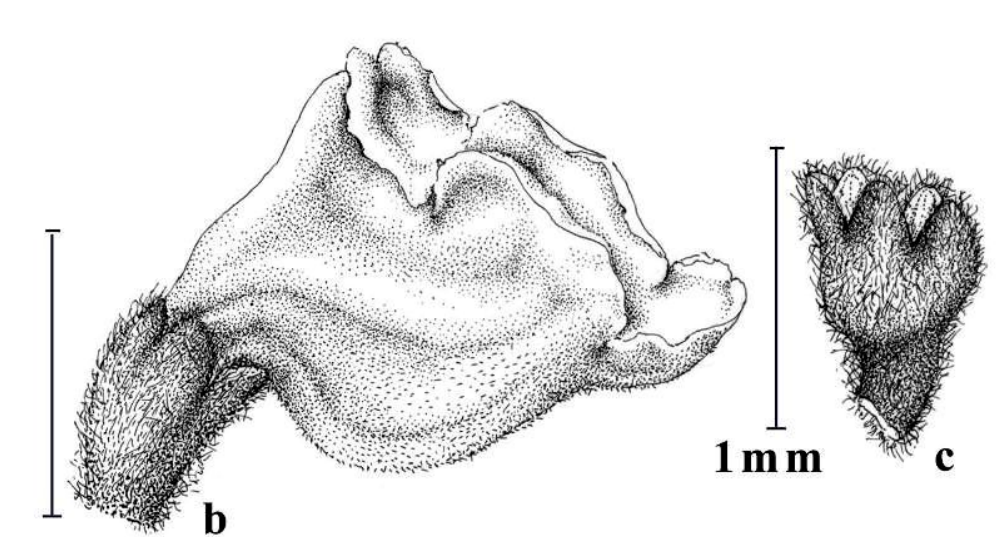

$1 \mathrm{~mm}$
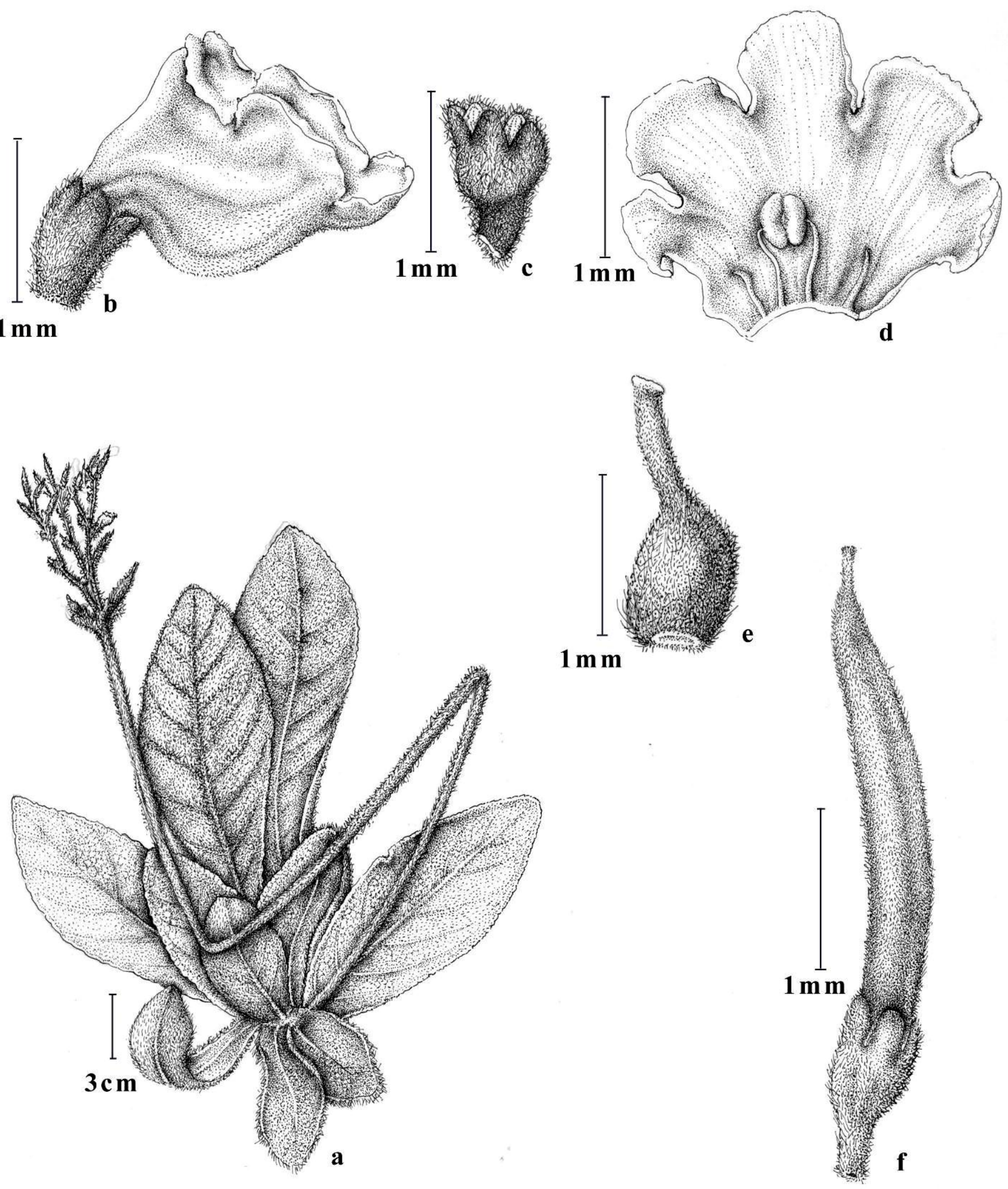

Figure 4: Henckelia macrostachya, a, habit; b, flower; c, calyx; d, petals (split-up); e, pistil; f, fruit 